\title{
CULTURE OF THE CAUCASUS BANQUET TABLE
}

\author{
Muhamed A. Shenkao \\ North Caucasus State Humanities and Technology Academy \\ Cherkessk, KCR, Russian Federation \\ science-almanac@mail.ru
}

\begin{abstract}
«Хъуэхъу» (verbatim: praise, boasting), khokhis good wish in verbal form, part of traditional life and culture of peoples. The place and time of the utterance of khokh define its direction, depth, complexity. On the other hand, khokh is the art of folk eloquence. They are pronounced for various reasons: the beginning of the labor of the peasant, the new moon, housewarming, the wedding, the first row of mown hay, the exit to the spring field, the end of sowing, etc. The ability to pronounce khokh for the peoples of the North and West Caucasus is an indicator of human culture. The slightest violations of drinking etiquette cause frequent or awkwardness, or a violent reaction. There is a lot of traditionalism here. It is shown that khokh is not just words to the place and time, but words-feelings, word-concepts, words-sacral, organizing and subordinating people. Based on the study, it was analyzed various forms of toasts: from the times of the Nartepicado to the present day. The culture of communication at the feast table is shown. It is emphasized that the Apsuara and Adyghea formed the style of thinking and behavior of the people of the Northern and Western Caucasus. The urgency of research of the given phenomenon for understanding and penetration into depths of national consciousness, historical memory and traditions of culture of the people is grounded.
\end{abstract}

Keywords: toast, praise, khokh, culture, tradition, the art of eloquence.

\section{[Шенкао М.А. Культура кавказского пиршественного стола]}

«Хъуэхъу» (дословно: похвалить, похвальба), хох - это благопожелания в вербальной форме, часть традиционной жизни и культуры народов. Место и время произнесения хох определяют его направленность, глубину, сложность. С другой стороны, хох - это искусство народного красноречия. Их произносят по разным поводам: начало трудов крестьянских, новой луны, новоселья, свадьбы, первой строки скошенного сена, выхода на весеннее поле, окончания сева и.т.д. Умение произносить хох для народов Северного и Западного Кавказа - показатель культуры человека. Малейшие нарушения застольного этикета вызывают зачастую или неловкость, или бурную реакцию. Здесь много традиционализма. Показано, что хох не просто слова к месту и времени, а слова-чувства, слова-понятия, слова-сакральности, организующие и подчиняющие себе людей. На основании проведенного исследования нами проанализированы различные формы здравиц: начиная со времен нартскогоэпосадо до современности. Показана культура общения за пиршественным столом. Подчеркнуто, что апсуара и адыгство фоомировали стиль мышления и поведения людей Северного и Западного Кавказа. Обоснована актуальность исследования данного феномена для понимания и проникновения в глубины национального самосознания, исторической памяти и традиций культуры народов.

Ключевые слова: здравица, похвала, хох, культура, традиция, искусство красноречия.

Muhamed A. Shenkao - Ph.D. of Philosophy, professor, North Caucasus state humanities and technology academy, member of the Russian Union of Philosophy, a well-known scientist of the Karachaevo-Cherkessk Republic. Cherkessk, KCR, RussianFederation.

ШенкаоМухамедАлиевич - доктор фрилософрских наук, профрессор, Северо-Кавказская государственная гуманитарно-технологическая академия,член РФО, заслуженный деятель науки КЧР. 2. Черкесск, КЧР, Россия. 
There are no deep, detailed studies on this issue. Although to understand the psychology of the people, their ideals, their sacramental states of the soul, their understanding of beauty, morality, understanding of the depth and scope of the people's world outlook, the research of toasts is necessary. In general, to talk (give a voice) to ordinary people in such metaphysical ways, i.e., fantastic, "imperceptible", immaterial notions such as beauty, hospitality, honor, divine things, dignity, eternal and passing, purity, girlhood, harmony in the home, in the world, and so on, are very difficult in the normal, "secular" time.And only during khokhs (giving toasts, loftly words to the hero of the occasion), relaxing after the righteous works, people begin to speak with loftlystyle, poetic speech, bringing out the purest and highest in thought, that is inmost, that not everyone would be told, and not everyone would be shown, that is, the ability to speak and think.

In our study, we rely on materials (empirical ones and research) Sakiev A., KardangushZaramuk, NaloyevaZaura, Inal-Ipa S.D., Bigua S. and others who work fruitfully in this field, or rather in the field of folk culture. "Хъуэхъу» (a khokh is good wishes in the verbal form) is a part of the traditional life and culture of people. Khokhs, as good wishes, are not always opened and not everywhere, but only at a given place and at a given time, i.e. at the time of "pialje" (= time, the intersection of time and a place). the time and the place the khokhs utterance define its direction, its "depth", etc.On the other hand, khokh is the art of folk eloquence, and as such it came easy not to everyone. The man who began to give a special khokh (toast) was supposed to learn from others for a long time.

The performer of khokhs in his own studies had to memorize and keep in mind some clichés of thoughts, special, unique figures of speech, memorize and speak his own thoughts considering what was said before him in order not to repeat someone, and to say what was permitted, to speak fluently at this point, at this stage, in this house, and not to be ahead of the events and the elders, that is, didn't disturb the etiquette of the banquet table.

At the same time, researchers and observers of Caucasian toasts (and the toast is the outward form of a khokh) note unanimously that the words are "incendiary" for hearts here, that is, in the course of giving a khokh, the "strings" of souls are touched verbally which leave no one indifferent by age, sex, race and culture.Already in the 15th century, European Interiano said that both drinking and khokhs are committed here in the North Caucasus with all seriousness, just like any other case. So Interiano wrote: "They drink all the time, and in the glory of God, and in the name of the Saints, and for the health of relatives, and in honor of the dead friends, and in the memory of any remarkable and important feat, and they drink with great solemnity and honor, as if doing a rite, always with naked head and in the mark of the highest humility" [4, p.49].

Khokhs can (as an exception in the 19th century and now often) be pronounced by women. But akhokh is "the word of Man", i.e. a firm, solemn word, "men's speech". And if a khokh is the word of a man, it is assumed that the younger one, and especially the junior one according to the rank at the table, (and they often fill glasses) "Bzhjekujes", must listen to khokh, the word of the elder, for respect, standing. Also for a woman, a mother of many children, people listened to akhokh and drank standing, for respect to her, to maternal work. It was believed that the speaker who spoke beautifully did it on behalf of God, that God "tkhie, anchva", put in his mouth the highest, noble words of the people. After a khokh, the people thanked the speaker for expressing what they had in their hearts and minds ("di gum ilyrZhypiai"), that he did not damage their reputation in eloquence ("Dybgjeukiitakmi, Dikjepshjekhuzhai").

Nowadays, everyone understands that khokhs are no more than table decorations, that they are a beautiful fantasy of a speaker, but at least sitting people at the table want all khokhs to come true, to materialize. At least everyone wants any good wish to be toasted, fixed, asseverated, i.e. Adyghe "Traiujenu". It was believed that through a toast, a 
phenomenon, a thing or a person was sanctified, and therefore nobody could put the evil eye, the whammy on them, they wouldn't be in an accident. «Xъyэхъy»is word-for-word: to praise, bragging. The highest khokh is certainly from God or Gods. In the "Nart"epic Sosruko received it, for his acts in the name of national nart goods.

Great old man, hero of the epic Nasren-Zhache, taking the word from toastmaster, gave his blessing with the khokh, the good word to Ashameza, Nart Orpheus [6, p. 246247]. Getting good wishes from the hero is no less important than getting a khokh from Gods, because he (hero) has seen many things, much has been done, that is, he is almost like God. So Adygeis have an expression: "tkhjem and psaljemutyregjeuvje; spkhujedjeshhthjepjelyti, narthahujem and psaljergujegunjekhuutregjeuvje", which is in the translation: "The Word of God puts on his feet, and also the words of the God-like nart hero put on the light path." The khokh of a toastmaster (tkhjem and ade), the messenger of God, everyone listened silently and standing at the table. Moreover, the line of behavior at the table, the theme of the khokhs was determined by the first khokh of a toast-master. The word of a toastmaster is a law for everyone sitting and serving at the table. The speech of a toastmaster must be logically constructed, cleverly, with flashing jokes, with the observance of all decencies and traditions.

Adygeis say: "Gupshysi-Psalje", "First think and then speak." Therefore, Adygeis respected those who "zhabzjezyiulu, shjeryujeupsaljer" (= who had the eloquence and well, appropriately and at the right time, precisely hitting the mark) said, even if he was an ordinary messmate or even the younger one standing at the table above the senior or temporarily invited people to the table.The beautiful, affectionate word amazed, amused, gave the opportunity to lose oneself in dreams, relieved the soul and the body of a person from secular concerns "si gum bampijedjebgjekiai" (= "you've taken a load off my mind").

In the educational system of the Adyghe-Abkhazsky knightly consciousness, the words-suggestion (suggestii) played the prominent part, they were received through the instructions in the khokhs. A person completed in khokhs his education, new truths and the expanse of being became opened for him. Universities completed at the table the pyramid of his education and civilization. The truth of life was revealed to him, the transcendent meaning of human existence and the concepts; simple ordinary words received refined forms and meaning; here in the course the khokhs, the person was given cognitive conceptual knowledge with the moments of abstraction and sensual reflexing in the form of word-images [9, p. 27].

In the view of the mountain warriors, by teaching a person through akhokh in the line of his fate, in the bone, the body was amended, i.e. social things interfered in the biological ones.So, as a child, Nart people foreboded Ashamezua beautiful Knight's life: In order that he would have countless years of life, Psatkhje (= God of the Soul) would be his patron, that he would overwhelm enemies, that he would be like a rider being worth the whole army, that his one blow would be equal to 100 strokes of simple ones, that no one would get away from his arrow, that he would destroy half the troops by his sword, that everyone would surprise who would hear him, that he would be the guardian of the village, that the harvest of the millet would break his barns, and his sword was always sharp; And God Psatkhje did not leave his rooms, and Tkhagaledzh would always talk in the field and in the lowland that his life (Ashameza) would be without end, would be everlasting, even if he could be a strong root of our nart people. Praise him [6, p.246-247]. Nart-warriors are rough, laconic, closed for strangers, they can open on their own, as we have seen above, to relax before the miracle of nature, before the birth of a child. In a khokh, there is naming of a child-it is done in advance, from the top, from God, that goes without saying, that is, the name is defined before a birth, the child was born with the name, this is the characteristic of the epic. 
Opening up their mental secret nart-warriors can only do it at the moment of the greatest excitement: During the blessing the pure, holy hero-child Ashameza with the khokh. The beauty of the world is framed at the nart people, outlined by a severe military life. Military valour, the ability to survive, to conquer the enemy by force, smartness, and sagacity - all of this was both beautiful and true in their own and other's eyes. If in the heroic time, within the framework of military democracy, valour flattered nart people in relations with aliens, then, at the same time, in relations with their people, knowledge and behavior were "beautiful" (aesthetic-ethical) within the framework of decency. Adygeis talk about it: "Kekiukemykiuzjekhjezyshhiykiyrzhiykhushh", that is, "who distinguishes decent and indecent things, that is the man". This idea is held in the khokhs of our day with the expression "zjekhjeshhiykiiijeumjepsalje".

The beautiful girl is marriageable, the beautiful bride is in all the folk texts, in all the folk verbal creations, and especially perhaps in khokhs [7].In khokhs the beauty ideal of a Caucasian girl, a young daughter-in-law, is described, who crosses for the first time a threshold of a new house. According to the good wishes a bride must: whisper words silently, like a sheep, like a babbling creek, like sounds in the fermentation of wine or "makhsymje" (the millet Beer), be like a lamb, like a hen- caring for children, as a good horse -famous (by breed, descent, or state-M.Sh.) as a bird-chirped. Here, we see the peasant observation taking away from each of the animals a trait, a close man, something soft, gentle and humanized. The hair of a young girl is compared with the mane of a lion (lioness), she sits in a chair like a dove, stretches out like a lion, eyes like a star, a body like Crimean cotton, cheeks like red apples, "sjekhusjeplrjes", breasts like apples, eyebrows like pearls or crescent, her back is straight, her face and neck are white [1].

In all these comparisons, objects are from the visible world. Symbolic, sign thinking ascribes to them all the hidden qualities known only to the people in the region.Thus, "Asljen" (lioness) is a symbol of inaccessibility, power and awesomeness, a dove is gracefulness, a star is a symbol of clarity, purity, a cotton is a symbol of softness, etc. But the beautiful things Adygeis and Abazins saw not only in appearances, but also in deeds. So, a young daughter-in-law, according to a toast, was supposed to be hygienic, "don't break up with a switch," sew well, so that she sews would not be at the seams, she shouldn't like to sleep, she had to cook the food well. It is specifically stipulated that she should be slim, not thick and not thin: "Kjerjekatinjeu, Bjerjetinaguje" - and particularly beautiful it was considered a girl with a white face, black hair and blue eyes. In general, they often single out according to eyes: "Dakhjenaguje", i.e. "beautiful, blue-eyed" (there is even a female name). It was also considered a beautiful "njekujeljen", i.e. odd-eyed, green-eyed. By calling the daughter-in-law "fo" (honey), whoever gives a khokh, immediately adds, emphasizes the components of feminine beauty: Eyebrows like swallows, hair to heels ... The Bride (Nysje) is valued for obedience to the Mistress (guashhe), the mother-in-law. And at the same time, in a khokh they ask "that the language will be gentle with the Mistress", (Uibzjegumfoteluepsalje), that is, that you should have honey on the language, when you speak, Adygeis ask. She should have avoided seeing father-in-law (the groom's father). Before the father-in-law resolution, mountain customs she could not talk to him. The bride is also charged with the obligation to adhere to the "Habze", that is, the natural right of the mountaineers, and also to live the "Namys" (morality), the "NartHabze", that is to adhere to the highest heroic morals, where the duty, hospitality, the law of honor are above everything. The bride was also valued as follows: Was it independent, and carried any case to its conclusion?

So, in a khokh they ask: "ZydjekiualujehumliyKijelymykiujezhu", i.e. that men would not finish her case [1, p.96].

It was believed that the bride, i.e. nysje, Atazha (Abazinsky) should know the fear and shame in the face of the mistress. It's something tyrannical, patriarchal. But apparent- 
Iy, thus, the young nysje be to take up the interests of the family, the anxiety of the oldest, who always felt that the House should be constantly lit (the unquenchable fire) of the hearth (the symbol of life), that housewifely become the first habit, the number one for the young "Atazha", that she would be constantly worried: Is there hot food in the house, are the children healthy, are there comfort and peace for the husband?

In khokhs they ask for: In order when she gives a birth, in a month after the birth, they can mount, so in other words in order that they will quickly grow, "in order the house of the bride to be full of guests", so that many people will go to being young- that is how people thought of happiness and beauty.

It was also a wish (usually made by guests before leaving), that the table that the bride "raised", that is, could set, would feed the whole Kabardakh, and the food from her desk would make all the girls beautiful ("Thjeiukhud"), i.e. the bride's assessment was in her kitchen level. Food, like something sacred, sacral, had to be prepared by a young, healthy, beautiful (internal and external) girl.

According to a toast it was regarded as a beauty, that the words of bride were soft, like honey, that the flames of her heart would be about the house, for her children, that she should always be a bright and light face; "to have a long throat for people", that is, that she should have patience and would not raise her voice; that a bride wouldn't think about bad things "khjeram" (kosher), that she would maintain the reputation of a new family (i.e. morality), where she came after her husband (it was considered a shame for the mountain people to be an adoptee/primak); that a bride would move quietly, noiselessly, and her step would be similar to the movements of a doe, a deer (= blane), i.e. graceful [1, p.79].It was also a good wish that they, the young ones, would have plenty of wealth, gold, silver ("ueziy", "vestal"), money, and especially "golden children".

About "Golden posterity" it is more said than about real metal. By "golden children" was meant a well-bred prosperity, who, according to the figurative expression of Abazin, " it isn't a pity to give a heart to eat" (= Upsyiudurfi). In golden children, high moral qualities had been put since a birth through a certain mountain system of upbringing. Now, Adyghe old people are going to tell you: "I have two sons." One stands constantly on my soul (that is, he contraries to everything). And the other son goes always to meet my heart, my wishes, and I would give him my heart, that is, "Sigumkypylydjeu, sipsyrZjezgjeshhyn", seizes my meaning at once. The first son's name is "kin", i.e. "stubborn", the second "spsy", i.e. "my soul". And perhaps "the golden child" will be "Spsy", who has "khial-shan, Adab" (= the character, discretion, breeding, discipline).

The bride was wished that where she had gone (the parent house), she would leave the golden trail of heel, and the house in which she came, brought the day with her legs, the socks. They say so:

\author{
"Kyzrashami- \\ LjedakjeMahujeKahushhinje, \\ Kyzdashami- \\ LapjemahujeKahuihahje. \\ Georgian Kyshhiigjeki! " [1, p.103-104]
}

Apparently, the tracks that the bride left behind were regarded as sacral places, because her thoughts, like no one, were pure, the best thing of feeling that could be, was love, moving her to a new home, to create a new hearth. Thus, we see how in the toast, the haughty souls of the mountaineers were revealed with beautiful sides. Their beauty ideal is a pure, tender, almost airborne, fragile creation of nature - a bride who, at a new stage, is waiting for a new one, as it is said to love with passion, wish everyone well, it is a pure, open soul. And apparently, the thoughtful, wise souls of the mountaineer caught the gentle tenderness of the young soul. And her one, through khokh, was calmed, helped to over- 
come the excitement, and the words about her spoke in unison with her heart, i.e. They spoke instead of her about what she was thinking. In the khokhs of our days it is said that the bride should also study after marriage so that she would take refuge in the profession as in the house and that, whatever she conceived, all this would be reasonable, and that from her hands the good would be poured, and that she would glorify the new father - the master (the old man) "ipzhchizh", and that the heart movement would be for the mother (= anem and psemlurytu) of her husband.

Inkhokhs of recent years, certainly, the changes areconsidered that have taken place in recent years: europeanization, freedom of the will of the young people, at the same time, there is always the desire of young people to hold to "khabse" so that "khabserubzeyaflemyschiu", i.e. so that customs will not be called flattery, so that the natural law will not be degraded to servants of guests, will not serve for sweetening. Apparently, this khokh is addressed to a girl from a different culture [1, p.103-104], so that she understands that all wishes are serious and permanent, and that they should become part of her nature, character, they must enter the blood and flesh as an order and the basic law of family life. And almost always in all toasts a speaker calls himself for help and in witness the most powerful personality of the universal scale - God. Therefore, there are always expressions in the endings of khokhs: "Thyemkyidit", i.e. Let God give us, or "thyemkaeshchligjekl," that is, Let God give us what we think of her, or "kuhedratkhemutkhuigjepseu," that is, Let God grant us that she may live long; Or "Apkhuedeniseukjidet", i.e. Such a bride God grant us, - thus asking the indifferent Most High. In the khokhs, the people do not strictly observe who is who in witnesses: Tkhje (God) or Allah. For the people the days of merriment, they're identical and interchangeable. It is also interesting that during the years of totalitarianism in the toast about Stalin, they asked Allah (!) to give the great leader (who himself neither in God, nor in the devil, nor in people believed) health, inexhaustible long life.

In 1947, when this toast was written about the leader, there was a famine in the Cherkess Autonomous Region, and Stalin was asked as God: to send them, peasants rain and grain Indeed, it was difficult to understand: where are the forces of the extraterrestrial God (Tkhje or Allah) terminated, and where does the functions and powers of the earthly God (Stalin) begin, and who depends on whom? Totalitarian consciousness produces aberration, overturning of values, substitution of tradition by a surrogate, this, as we see, did not escape good wishes. Guests and compatriots from Muslim countries, coming to us, and looking at our khokhs, are surprised at how we combine often incompatible things: we say a khokh, we ask Allah for something, with a glass of vodka or wine in hand. This is like what $t$ great Omar Khayyam wrote about:

\section{In one hand - a glass}

The other one is on the Koran,

And so, we live under the blue sky,

Semi-gods and half-Muslims.

Adyghe-Abazino-Abkhazian mentality cannot take a khokh without alcohol "arqje". Apparently, this is the influence of totalitarianism. Mountaineers before the revolution raised glasses with "bakhsyme, khu fade", i.e. bouza, millet drink, which strength approached beer, but no more. The culture of drinking, feasting, libations (if we can talk about culture in this case) has surpassed all measures, and now, we, figuratively speaking, drink and destroy our genes. The genetic future of our children, of our nation through alcohol, we expose to a great, if not fatal, risk.

Returning to khokhs, we see that they are different. They are pronounced as rituals on different occasions: the beginning of the labor of the peasant, the new moon, housewarming, the first plow in the spring, the first furrow, the first row of mown hay, the exit to 
the spring field, the end of sowing [1, p.17-56].There were khokhswhich were given by Gods: from Amizhsh (God of cattle), where the natural words were: "so that as the lake was milk, like the wheels of cheese, the sheep account would be innumerable, like the stars in the sky." Such concepts as the beauty of the soul, generosity - the people would like to turn to themselves in the name of God and impregnate their being with them.

The mountaineers also have the sacred khokhs about food on the table, about the generosity of the table. They are usually pronounced according to etiquette at the end of the feast, when they bring and put on the table the famous "Nish" - half of a ram head. This is the signal of the hosts about the end of the feast and it is addressed to the guests. At the end of the toast in such cases they say: "So that it would be 1000 years!". And this wish is given not with drunken seriousness, but quite sincerely: This is dictated by the mythic-epic, heroic nart nature of the mountaineers. These are the remnants of chivalry, the generosity of the soul. It comes from the traditional culture of the mountaineers, from the past structures of mentality. In the past beauty manifested itself in a gift, a broad gesture. And the person who gave a khokh at the table, as if expressing the opinion of the group, gave as his best to this house, the hearth, the hostess and the table -1000 years.

Toasts were pronounced in the name of son-in-law or son, when they were respectively invited to the home of the parents of the bride (schauetekhje), or when his son was called back to his house by his parents. It is noteworthy that in khokhs there is no description of the appearance and body of the man (this would be shameful to his honor); In contrast, in the khokhs there are the wishes of the great acts and the exemplary type of behavior: "Fi gjashlerkiikhju", i.e. Long life to you, "Fi namysyrljageu", i.e. Deep happiness to you; "Fi Akjylyrkhurikjuu", i.e. If only you have the good sense; "Gukhjekhuer fi kuedu", i.e. Much Happiness to you; "Fadebzhjarzefkhjefu", i.e. So that the glasses you can raise, drink, but do not get drunk; To live according to the Adygian saying "Efe-efeumiudafe", i.e. Drink, but do not get drunk; "psherikhjipbgjebef", i.e. So that you can cook fatty meat [1, p.113]; "Tkhjemfigjepseu", i.e. So, God gave you to live. As we see, for the man in khokhs there are given other instructions, other values and other concepts that determine his dignity[10, p. 20].

And right now, the man is said he mustn't see a woman's tears in order not to be touched. And he must never show tears [1, p.115], that his moment of weakness will never be forgiven, and men's tears are worth more than his blood. As a man, this weakness does not suit him. Here, the beauty of a man is revealed in his stamina, in firmness of spirit, in restraint and in manners of behavior close to aristocratic. Truly, as in the Arabic proverb: "The woman's mind is in her beauty; the beauty of a man is in his mind." A man of the kin, the head of the family, the one who gives a toast, now, after the marriage of the son, tells him that he (the son and his family) is now a separate unit of the kin, hence, now he must have his own pride, his own line of behavior, his own beauty in the behavior: "UE siShhialje, Uzhikiukhunkie-Uzigupashh, In ukhjuri-uziljepagshh, Fyzkapsheri-uziunekujeshh" [1, p.113].

Becoming a congener of a father (unekjuesh) obliged to much, and most importantly, the social recognition came as a Man, who was responsible not only for himself, but also for children, wife, relatives. Abazins talk about such a time of manhood: "JzamanAkhazhara zaman jtalti", i.e. he joined the prestigious and difficult male age, where(if not everything) many things within his grasp

Khokhs are especially numerous among Abkhazians - Christians. The art of eloquence, good wishes reaches a high perfection, aristocratic spirit, here, on the ancient land of Apsna, The Abkhazians also pronounce the khokhs on glad and sad occasions (on the occasion of death, remembrance). At the same time, during the funeral, the khokhs (toasts) have following themes:

1. Drink the surroundings. 
2. Neighbors.

3. Missing people.

4. Dead people in the war.

5. the repose of the soul.

6. The family of the deceased- this is the final toast.

During the funeral, there are 18 themes for toast [2, p.44-51].Toast is an external manifestation of a khokh. Khokh can be without a toast and without a glass, especially if it is pronounced by a believing old Muslim man. A khokh is a tradition, and toast is just a form imposed by civilization. A toast for an Abkhaz is an important moment in his life, at this time he, as it is, passes an exam for intellectual maturity before the whole world. National poet of Abkhazia BagratShinkuba wrote in the poem "Toast":

We'll toast for the start,

Clinking a thin glass sonorously,

For men! A Real Man

He doesn't lose his mind at the table.

He must not touch wine,

Whose soul is crafty and troubled,

It is not to the men's

That his tongue refuses to obey him,

Only a drunk can drink,

And he doesn't know how to do it

At the table thanks to the wine no one become clever

The one who seeks the truth at the bottom [2, p.47]

At the table, they do not drink for the sake of sporting interest - who will win in drinking, but for the sake of cheering up, for the sake of the fun of the soul. At the table, Abkhazians strictly look after themselves and their neighbors: is the "Apsuara" ("Abkhazia") observed. It is like "Adygagje" ("Adygstvo") - a way of life, a way of thinking and behavior, i.e. traditional mentality, which makes Abkhazians - Abkhazians, Adygeis- Adygeis. In Apsuara and Adigagje, the best aristocratic features of the behavior and thinking of people were included. Through them, the people show the measure of their civilization, openness to the whole world. But through Apsuara and Adygstvo, people defend their national identity, their individual uniqueness, not wanting to dissolve and disappear among the millions of ethnic groups, i.e. Apsuara and Adygstvo are spiritual ways of self-preservation of people before the onslaught of European and electronic civilization.

The ability to pronounce a khokh for the people of the North and West Caucasus is an indicator of a personal culture. The slightest violation of drinking ethics is caused by Abkhazians either embarrassment, or a disruptive reaction. There is a lot of Eastern traditionalism here. The author of these lines was a witness when, in the opinion of the Abkhazian, the order of giving permission by the elder man was broken (permission for khokh).

If mountaineers of the Karachayevo-Circassian Republic have a tradition of transmitting the word, the permission to give a toast is determined by the precedence and the order of the seat at the table, this is not in the same way at Abkhazians. This order of good wishes from the Abkhazians is well described in the book Inal-Ipa [3, p.112]: By degree of honor, khokhs are given:

the 1 st one is the senior master;

the 2 nd one is the elder guest;

the $3 d$ one is the senior person of a community;

the 4 th is the main guest; 
the 5th one is a maternal uncle and so on, and there are only 23 ranks; And after the 24th rank the others give a toast. But everyone listens carefully each other. In this case, the violation of the rank, inability or "weak table management" can end at best by a polite leave of the celebration. In this case, for the traditional thinking Abkhazian, to remain behind one, a "spoiled-conducting" table means insulting himself, which he will never permit himself. The plebeian table and plebeian speech is not for the proud "Apsua Akazha", i.e., an Abkhazian.

Thus, as we have seen, a khokh is not just words to a place and time, but wordsfeelings, words-meaning, words-sacral, organizing and subordinating people. In toastkhokhs, the notion of the people's beauty, their morality, decency, etiquette, truth is concretized and detailed.

Certainly, no one can live on the pattern of khokhs- these are ideals. But all people at people's gatherings, at these peculiar universities of the spirit, absorb the best examples of speech, behavior and thought, and in everyday life they "clean" themselves under the ideals, values and norms of the khokhs. Everyone strives to live better, and in this they are helped by the equality in some way to the standards of toasts.

The well-known Adyghe researcher of culture ZaurNaloyev is right when he says that the khokhs were finally given to wish for happiness primarily (= nasip). And the happiness was understood different things: It is both a rich harvest, and large herds of cattle, and beautiful clothing, and health, and the day of the bride, and children, and a good house, and household items, and peace between people, and the violation of the enemy's plans("Zhjegujegu") and envious [5, p.5-14].

A similar phenomenon is also observed in Ossetians, this is a prayer that is pronounced before the bride enters the house. It is often spoken by a man, sometimes an elderly woman, with a bowl of beer in her hand. "Prayer have a certain canon, they can be divided into three types:" oration, a wish for two related surnames, wishes for the bride. At a modern wedding, the saying of prayers remains obligatory. The praying turned into parting words, in which one of the bride's relatives, at all the gathered guests, instructs her how to behave in the new house, he tries to remind her that she must love her new family as she loves her one, and even more" [8, p. 54-55]. We see, therefore, that toasts are multifaceted, comprehensive, i.e. Are stereoscopic in their coverage of reality, and they are waiting for new research for their adequate disclosure. Khokhs are hymns of hearts, and people uttering them only in special, solemn minutes reveal their rich inner world, their mentality.

\section{Лumepamypa}

1. Адыгэхъуэхъухэр. Налшык, Эльбрус, 1985.

2. Бигуа С. Абхазское виноделие // Эхо Кавказа. 1992. №1.

3. Инал-Ипа Ш.Д. Очерки об абхазском этикете. Сухуми, 1984.

4. Интериано Дж. Быт и страна зихов // Адыги, балкарцы и карачаевцы в XIII-XIX веках в известиях европейских авторов. Налшык, Эльбрус, 1974.

5. НалоЗаур. Адыгэм и псалъэдахэ // Адыгэхъухъухэр (Собрал КардангушЗарамук). Налшык,1985.

6. Нартхэр. Налшык, Эльбрус, 1951.

7. Сакиев А. Здравица // Ученые записки КНИИ. Нальчик, 1948. Т.4.

8. Хамицаева T.A. Свадебная обрядовая поэзия осетин // Эхо Кавказа. 1994. № 2.

9. Vigel N., Zholobova I.Heroic epos of North Caucasus nations as basis for ethnical culture of Adygea people // НаучныйальманахстранПричерноморья. 2017. № 2. http://science-almanac.ru 
10. Shenkao M.People of Caucasus and Black sea region: oratory skill// НаучныйальманахстранПричерноморья. 2017. № 2.

\section{References}

1. Adygekhuekhukher. Nalchik, Elbrus, 1985.

2. Bigua S. Abkhazian winemaking // Caucasian echo. 1992. No1.

3. Inal-Ipa S.D. Essays on the Abkhazian etiquette. Sukhumi, 1984.

4. Interiano G. Life and country of zikhs // Adyghes, balkarts and Karachayevts in XIII-XIX centuries in the news of European authors. Nalchik, Elbrus, 1974.

5. Nalo Zaur. Adygem and psalyedahoe // Adygekhuekhukher. (SobralKardangushZaramuk). Nalchik,1985.

6. Nartkher. Nalchik, Elbrus,1951.

7. Sakiev A. Toast // Scholarly notes. Nalchik, 1948. Vol.4.

8. Khamitsaeva T.A. Wedding ritual poetry of Ossetians // Caucasian echo. 1994. No 2.

9. Vigel N., Zholobova I.Heroic epos of North Caucasus nations as basis for ethnical culture of Adygea people // Science almanac of Black sea region countries. 2017. № 2. http://science-almanac.ru

10. Shenkao M.People of Caucasus and Black sea region: oratory skill // Science almanac of Black Sea region countries. 2017. No 2. 